\title{
RESCUE ARCHAELOGICAL RESEARCH AND ITS IMPORTANCE IN THE PROTECTION OF CULTURAL HERITAGE
}

\author{
J. Frolík ${ }^{1}$ \\ ${ }^{1}$ Institute of Archaeology of the CAS, Prague, frolik@arup.cas.cz
}

Commission V, WG V/7

KEY WORDS: Archaeology. Rescue Archaeological Excavation, Protection of Historical Monument, Archaeological Community

\begin{abstract}
:
Thorough knowledge of the area on which the construction or similar activities are to take place is the basis for responsible decision-making and for the elimination of unpleasant surprises. Central Europe is an area where archaeological monuments can be discovered on almost every plot. Their presence can mean expanding our knowledge of the past and significantly enriching our cultural heritage. The builder often sees the presence of archaeological sites as an obstacle. The position of archaeological monuments in term of ownership is unusual. The land is usually owned by builder, but the archaeological findings themselves are the property of the Regions according to the Act on Protection of Monuments. Archaeological monuments can be examined on each plot by non-destructive methods that determine their extent. The following is a decision as to whether the original plan will be implemented or withdrawn. Implementation of the project is preceded by rescue archaeological research, the course of which is also regulated by law. Carefully executed rescue excavation means saving the testimony of the past and the importance of the place and for the builder to release the land for implementation of the project.
\end{abstract}

\section{INTRODUCTION}

The management of any land is associated with respect for various facts, requirements and regulations that need to be addressed. The proven or only presumed presence of archaeological finds (small movable finds and terrain situations, i. e. layers and features) is also among such facts. This situation is the result of a long development, during which archaeological monuments have become an integral part of the national cultural heritage and very often also the centre of public interest. This happened in or territory and in other European countries at different times (Great Britain in the $17^{\text {th }}$ century, Italy and Sweden in the $18^{\text {th }}$ century, Germany and France in $19^{\text {th }}$ century). It was in the hands of interested amateurs at first and only later did it become a matter of appropriately educated professionals (archaeological lectures at Charles University in Prague since 1871). In the second half of the $19^{\text {th }}$ century, is it often associated primarily with the effort to document the great and glorious past of a particular nation (Czech, German, French). The emphasis on the national side has long been an impetus for the development of archaeology. It lasted until the $20^{\text {th }}$ century, but sometimes took very problematic forms (Germany in the first half of the $20^{\text {th }}$ century).

\section{ARCHAEOLOGICAL MONUMENTS BEFORE AND TODAY}

The interest in archaeological monuments has not been accompanied in our territory for a long time by any regulation that would set clear and respected rules for the protection, rescue and preservation of finds. It was also defined in the second half of the $19^{\text {th }}$ century, but was only

voluntary. The relevant institutions could only call for the protection and preservation monuments (including archaeological ones) and relied on cooperation with volunteers (Central Commission for Preservation of Monuments since 1872 in Vienna). The law on the protection of monuments (or cultural heritage) could not be adopted at this time, and the same was true throughout the period of the First Czechoslovak Republic. Nevertheless, already in 1919, the State Archaeological Institute was established in Prague as an institution providing care for archaeological monuments throughout the then territory of our republic (Hlava, 2021). The institute relied on a network of volunteers, because even the professional community was not large enough at the time.

The first legal provision was (paradoxically) adopted only in 1941 (Regulation of the Government of the Protectorate of Bohemia and Moravia No. 274/1941 Coll., On Archaeological Monuments - Blažek, Lutovská 2002). The regulation determined the basic rules for conducting archaeological research and defined the position of the Archaeological Institute as an umbrella organization and guarantor of a professional level. This regulation is recalled because its basic provisions have remained essentially to the present day and have also been taken over by laws adopted after 1945 .

The first law on the protection and monuments was not adopted until 1958 (Act N. 22/1958 Coll., On Cultural 
Monuments). The law preserved the central position of The Archaeological Institute (since 1942 with two workplaces in Prague and Brno and since 1953 part of the Academy of Sciences) as a guarantor of the professional level of conducting of archaeological research. It also introduced the register of cultural monuments in the form of a state list. The Act of 1958 was replaced in 1987 by new Act, which is still valid today (Act No 20/1987 Coll., On State Monument Care).

Efforts to pass a new law that would reflect the changes after 1989 have hitherto been in vain. In part, this replaces a total of 23 amendments of existing law. The most important is the amendment to the Act of 1992, which sought to adapt the protection of monuments to new social condition (Act. No. 242/1992 Coll.). It is currently unclear when the new law will be adopted, although the existing one is commonly characterized as unsatisfactory. However, in the field of archaeology, despite the shortcomings, the individual subjects are able "to live" with it (Zídek, Klusoň, 2005; Varhaník, Malý, 2011). Usually, it would be sufficient to consistently comply with and enforce the provisions of the law, including deadlines specified therein, by all actors. This is not only problem in our legal system (see the new Building Act).

The "Convention on the Protection of the Archaeological Heritage of Europe (Revised)" (the so-called "Malta Convention") adopted in La Valletta in 1992, deals with archaeology in addition to the Law on the Protection of Monuments. It was accepted in our country after some hesitation and efforts to soften some commitments only in 2000 . Its provisions are only voluntary, as each participant is presumed to sign a commitment to comply with them. It is understood only formal in our country and some provisions are interpreted in the opposite way to was intended.

Archaeological issues also appear in some other laws. Probably most important is the provision of the still valid Building Act (Act No. 183/2006 Coll., On Spatial Planning and Building Regulations) on the treatment of unexpected and extraordinary archaeological finds (paragraph 176). This can mean a very serious intervention in the building activities and, in extreme case, make it impossible. The paragraph defines the procedure for protecting the found monument. From the point of view of its implementation, the otherwise logical compensation to the builder for changes in the project and for cost incurred, to which the relevant state authorities are reluctant to decide, proves to be problematic. An example is the deserted Jewish cemetery in Vladislavova Street in Prague New Town (Dragoun, 2000; Wallisová, 1998). The discovery itself was unexpected, as no older building activities yielded graves or human bones. The cemetery itself was abolished in the $15^{\text {th }}$ century and the whole underwent several conversions and reconstructions. The discovery of the graves led to significant change in the project and media campaign. The declaration of a monument (archaeological site) as a basic condition for its preservation was postponed for an unreasonably long time and kept all participants in the construction work in uncertainty or the possibility of unintentional violation of other laws. In addition, the monument declaration was inaccurate, so that currently other builders in the same territory automatically calculate for financial compensation.
Archaeological monuments form a separate part of the set of all monuments (so-called monument fund) and have some special features. At the same time, their research (cognition) in the form of archaeological excavation destroys them. Archaeology destroys the source of its knowledge and the monument disappears. The excavation cannot be repeated at the examined archaeological site, because all terrain situations (layers, filling of objects) were dismantled and all fillings were collected from the original situations. The replacement for liquidated site is the acquired documentation (descriptive, drawing, photographic), which captures the original finding situation in as much detail as possible. That means that there is no substitute for sites destroyed without research in relation to the protection of monuments and cultural heritage.

Related to this is a different understanding of protection and rescue in relation to a particular monument. We understand as its protection it is kept in an authentic state and only sensitive interference with the building form if it is related to building monument. Repairing a poor building condition can be understood as saving the monument. Protection means preservation on its spot in an intact condition (within the intentions of the Convention on the Protection of the Archaeological Heritage) if it is archaeological monument. If the archaeological monument has to be excavated, i. e. preserve its historical and informative value (by obtaining detailed documentation), it is also understood by law as a method of protection, although this is not very logical.

\section{ARCHAEOLOGY IN THE LAW FOR PROTECTION OF MONUMENTS}

Archaeological research in our country can only be carried out by an organisation / person who has previously obtained authorization from the Ministry of Culture on the basis of statutory conditions and has an Agreement with the Academy of Science of the Czech Republic (in practice with Archaeological Institutes) specifying the general provisions of the authorization. On this basis, archaeological research is carried out by the Archaeological Institutes (the only ones without authorization, but by law), the National Institute fro Protection of Monuments, most museums and universities (where archaeology is taught) and since 1993 also by private entities (most often in the form of public non-profit society). Foreign entities were also allowed to conduct archaeological research on the basis of harmonization following the accession to European Union.

How will the archaeological organization find out about the activities that make it necessary to carry out archaeological research? These activities can be divided into two groups. One is connected with building registered in the state list of cultural monuments. In this case, the builder must obtain the opinion of the executive body for protection of monuments, which, based on the opinion of the professional body for protection of monuments, will determine the conditions under which intended construction can be carried out without suffering the status of the monument (section 14 of Act No. 20/87 Coll.). Protection of monuments is illogically divided here. The professional unit formulate its statement according to the 
long-term accumulated knowledge about each monument. The statement for builder is made at the executive body (i. e. usually at the regional office or municipal office). However, it does not have to follow the statement of expert file. Isolated attempts to employ an archaeologist at a regional or municipal office have never lasted too long. The statement of the executive body for protection of monument should also contain provisions on the implementation of rescue archaeological excavation and the basic conditions for its implementation.

The Monument Care Act also requires all builders (including those who proceeded in the manner just described) to notify the Archaeological Institutes of the Academy of Sciences of the intention to build on an "area with archaeological finds" and "from the time of preparation" (section 23 of Act No. 20/87 Coll.)

The "area with archaeological finds" is not defined in more detail in the law. It is assumed that archaeological finds (monuments), unlike most other monuments, are unknown (they are not visible on the surface, with the exception of mounds, ramparts or deserted buildings, which however, are a small minority among archaeological monuments). We can infer their presence on a specific plot of land only from indirect indications (a situation analogous to places where the presence is proven; intensive occurrence of archaeological finds in the vicinity, written sources for mediaeval period, etc.). Archaeological finds / monuments can occur more or less anywhere according to experience. An example is the known finding of mummy of "Ice Man" (or "Ötzi") on the ridge of the Alps (Spindler, 1998) or a mummies in the high Andes in Peru. Usually, excavated areas (surface mines, quarries) or flooded areas are excluded from the characteristics of "areas with archaeological finds". While the first case this is logical, in the second it does not apply absolutely. Interesting are finds from the Middle Ages in the pond of "Jordán" in town of Tábor, prehistoric settlements from the Roman period $\left(1^{\text {st }}-4^{\text {th }}\right.$ century AD) in drained and revitalized ponds in Horní Počernice and Černý Most or the prehistoric settlement and deserted mediaeval village Litožnice on the site of pond in Praha-Dubeč (Figures 1 and 2).

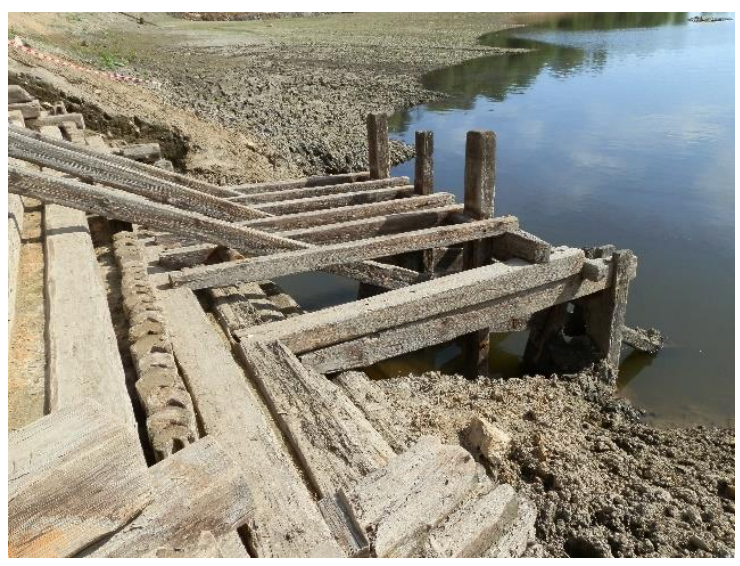

Figure 1. Tábor. Mediaeval wooden construction in the pond Jordán.

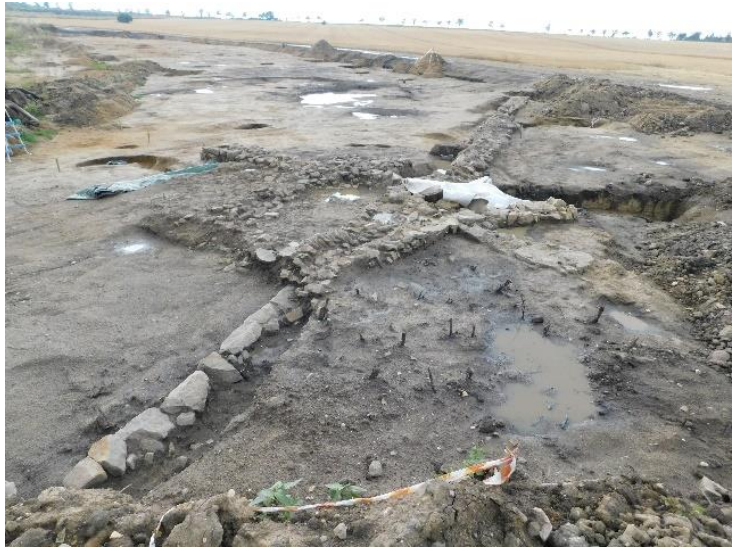

Figure 2. Praha - Dubeč. Mediaeval building of deserted village Litožnice on the bottom of the pond.

The professional scope of archaeology is also constantly expanding. The law does not define how old a monument must be in order to be considered an archaeological monument. Mediaeval monuments have been archaeologically studied in our country since the 1950s. Monuments from the $17^{\text {th }}$ to the $19^{\text {th }}$ century became the subject of research about 30 years ago. At present, monuments from the $20^{\text {th }}$ century are also being examined (e. g. military graves, mass graves of war victims). Proposal for a new monument law defined the archaeological monument's age of 70 years.

Therefore, the "territory with archaeological finds" is considered to be the whole territory of Czech Republic and the reporting obligation applies to all builders.

The announcement takes places today in the internet application "Archaeological Map of the Czech Republic" managed by archaeological institutes. The internet application made it possible to obtain an overview of all announced constructions and to facilitate the distribution of individual events to territorially competent organizations. The report is evaluated and the builder is informed whether the building activity will be accompanied by rescue archaeological excavation.

It is difficult to determine how many announcements of the total number of construction activities will appear in the Archaeological Map of the Czech Republic. Many construction events do not reach below ground level (e. g. roof repair), so it is not covered by the announcement. The estimate is between $10-20 \%$. It is clear that a (significant) part of the activities escapes the records and can be discovered rather accidentally. On the other hand, this amount is within the capacity of archaeological organizations. The law does not specify exactly when the notification is to be made ("from the time of preparation"). In practise, the notion that it can be almost until the beginning of construction began. Late report can lead to significant problems (construction delay, damage or destruction of archaeological finds).

It is appropriate to announce construction activities as soon as possible from the point of view of the smooth implementation of rescue archaeological research and at least possible intervention in one's own construction activities. Rescue archaeological research can be carried out in advance and thus completely eliminate the time 
delay of the construction or warn in time facts that would lead to a change in the project. Such a possibility is provided by the current Building Act, which divides the administrative procedure for receiving a building permit into two steps for most buildings.

"The first is the zoning decision. Then, with a certain time period, a building permit follows. It is the period between the two official acts that is most suitable for conducting rescue archaeological excavation (so-called advance archaeological research).

The announcement of the building activity at the place where positive occurrence of archaeological finds is expected leads to negotiations with the builder with the aim to concluding an agreement on rescue archaeological excavation (on its basic conditions, duration and cost reimbursement). The initiative is always on the side of archaeologists. Due to the fact that there are more archaeological organizations in each region of Czech Republic, the builder can choose with whom he will conclude an agreement. If no agreement is reached, the decision is transferred to the regional authority. This procedure is (fortunately) not very common. If it occurs, the region usually decides (confirms) the need to carry out rescue archaeological excavation.

According to the relevant section of the Monument Protection Act (section 23), the costs are usually borne by the company /person who caused the need to carry out rescue archaeological excavation (the principle of "who destroys, let him pay").

Reimbursement of costs logically follows from the unusual fact that the ownership of the land on which the excavation is to take place is not unlimited in all respects. The ownership of the land by a particular owner is not questioned, as is the possibility of disponing of it (within the legal provisions). If there are archaeological finds on the land, they are the property of the region, not only if they are physically elevated, but also in general in an "undiscovered" form and in a fully unknown form. It is part of the national cultural heritage, and therefore it is necessary to protect it from the destruction by construction activities, i. e. to save it in the form of archaeological excavation. It was designed by the builder, it is logical that he pays for the "transfer" of the findings from private land to the museum.

The Monument Act imposes the reimbursement of costs of archaeological excavation on all builders, with the exception of private non-entrepreneurs (in practice, especially person building a family house). This interpretation was not reached until approximately twenty years after the law came into force, even though the wording of the relevant paragraph is clear. Following the adoption of the amendment to the State Monument Care Act in 1992, thanks to the benevolent approach of top monument institutions and the considerable efforts of many builders to avoid costs, the range of buildings for which costs were not reimbursed with reference to "public interest".

This would not be a problem if archaeological organizations received part of their budget as directly dedicated to carrying out rescue archaeological excavation. However, no organization receives such funds and usually pays unforeseen expenses from its budget. Since 2006, the non-payment has been limited to the already mentioned builders of family houses. This can also be a problem if the construction is concentrated in large groups of family houses and in a short period of time (for example Mikulovice in Pardubice, where the construction of a colony of family houses in the area "V loučkách" (Figures 3 and 4) led to the discovery of a site whose significance extends beyond Central Europe - Ernée, Langová et al., 2020; Frolík, Sedláček, 2015; Jošková, Langová, Jílek, 2020). Also, most archaeological organizations do not receive the necessary funding for this activity.

On the other hand, it is not surprising that some builders are not willing to pay the costs and are looking for ways to avoid it, possibly reducing them as much as possible. The same applies to the time needed for archaeological excavation. Therefore, tenders aimed at the lowest possible price (costs) have been used in archaeology, even though they do not correspond to the nature of the activity performed (despite the best preparation, an increase in costs is also in direct conflict with the guarantee of professional quality of the work performed and the achievement of the necessary information value of the findings. There are also schedules for construction, in which a winter season with unsuitable weather is set aside for archaeologist (Figure 5).

These facts are usually not of interest to the contracting authority. The result is a forced resignation to the quality of documentation work or research of only a part of the built-up area, which is in direct conflict with the ethics of the field. However, the builder rarely bears the consequence for such an approach, problems remain on the side of archaeologists.

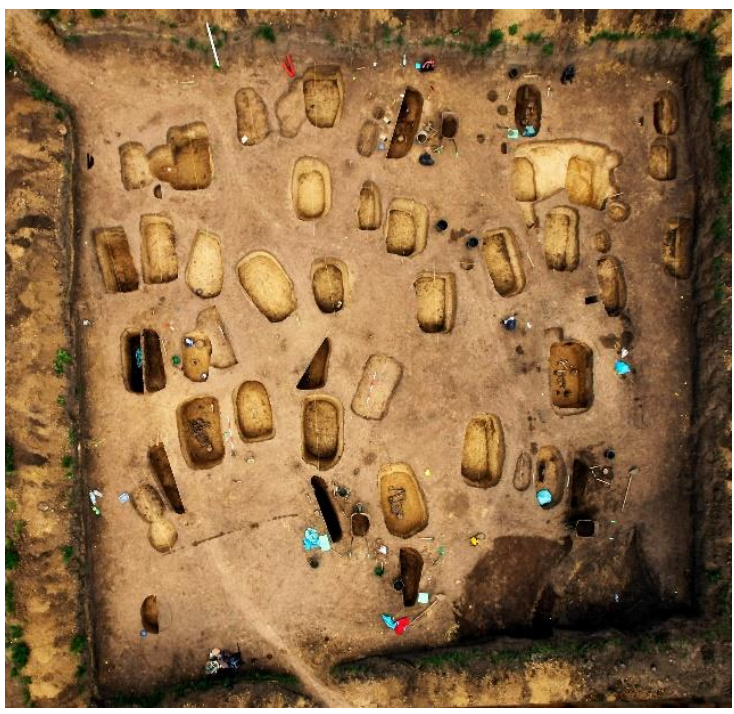

Figure 3. Mikulovice (Pardubice Region), "V loučkách" site. Area of a family house with a large number of graves from the Bronze Age (1800 - 1600 $\mathrm{BC})$. The research required a considerable amount of time and money. 


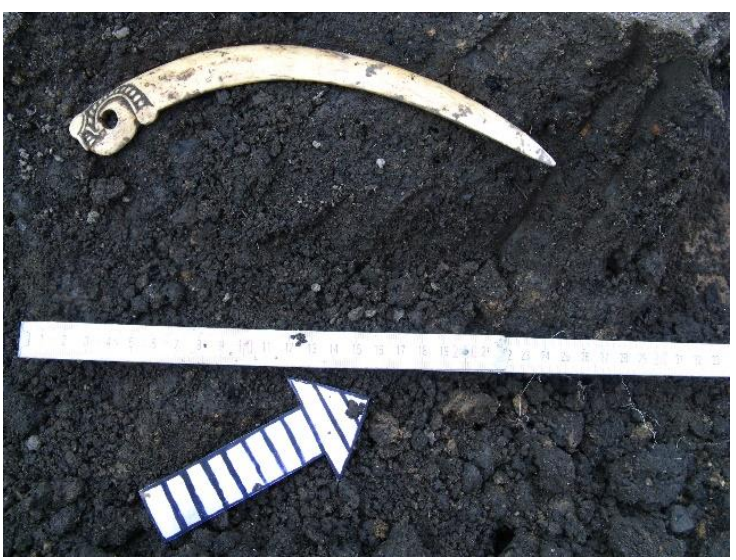

Figure 4. Mikulovice (Pardubice Region), "V loučkách" site. Bone part of a horse harness originating from Black Sea region $\left(7^{\text {th }}-6^{\text {th }}\right.$ century BC). Proof of long-distance contacts and the only finding of this kind in our territory.

The extreme case is places where the builder intentionally destroys the site (i. e. does not announce the building activities and removes the archaeological finds). If such a procedure is followed, the corresponding sanctions defined by the Monument Care Act (a fine of up to 4 million Czech crowns) should follow. The procedure of the institutions imposing the sanction is often lax and the fines imposed disproportionately low, often reduced or canceled later (Patrik 2020). No such case has been brought to court and successfully completed. According to the applicable laws, it is difficult to quantify the damage. It is not possible to determine unambiguously and precisely at the destroyed site how many archeological finds were originally located here. The proposed solutions (e. g. deriving damage according to a similar archaeological site or according to the costs that would be incurred in rescue archaeological excavation) were not accepted. The fact that they are invisible in this area is major challenge for the future.

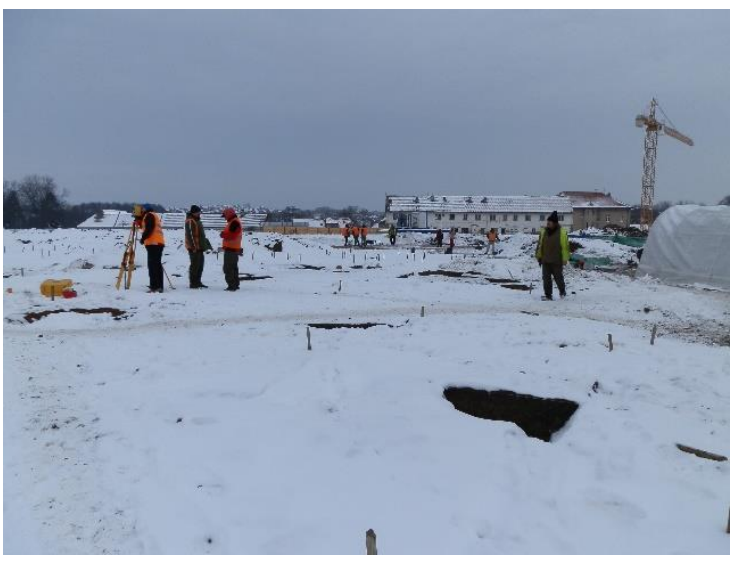

Figure 5. Dolní Břežany (Central Bohemia). Rescue archaeological excavation on the construction site of the HILASE project.

\section{ARCHAELOGICAL COMMUNITY}

The legitimate question is whether archaeology (archaeologists) is sufficient in number (capacity) for a large increase in construction activities after 1989 and thus the need to ensure the implementation of rescue archaeological excavation. A simple answer would state that not in its entirety, even though the Czech archaeological community corresponds in its composition and number to communities in other states of European Union (Aitchison et al., 2014; Cleary et al., 2014). According to the latest survey in 2014, 530 archaeologists worked in our country (Frolík, Mácalová 2014). According to the same survey, the usual size of the archeologists' community in the European Union is $0,02 \%$ of the population in each state. In addition, only some archeologist work on rescue archaeological excavations. The main activity of some archaeologist is teaching (universities) or theoretical research. Archaeologist are also unevenly distributed in the territory of our state. $29 \%$ of them work in Prague institutions, 22\% in South Moravia

(i. e. mainly in Brno) and $10 \%$ in Pilsen Region (i. e. mainly in Pilsen). This means that $61 \%$ of archeologists work in three regions (not randomly in those where intensive construction work is taking place). The opposite is true of the four regions (Karlovy Vary, Liberec, Vysočina and Zlín), in which bring together only $6 \%$ of all archaeologists (Figure 6). The size of archaeological workplaces is also problematic. It is obvious that a larger number of larger excavations at the same time (a common situation today) cannot handle a workplace with a single archaeologist. Nevertheless, there are $44 \%$ of such workplaces.

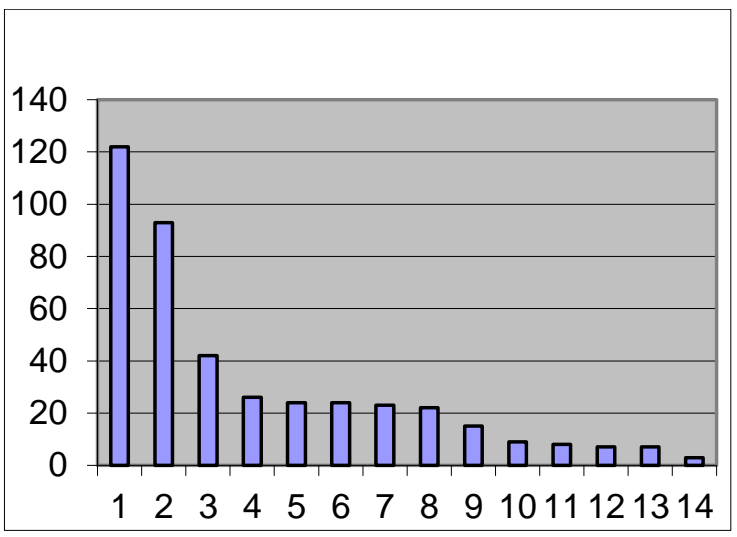

Figure 6. Number of archeologists in individual regions of the Czech Republic. 1 - Praha (122 archaeologists); South Moravia (93); Plzeň (42); Olomouc (26); South Bohemia (24); Central Bohemia (24); Ústí nad Labem (23); Hradec Králové (22); Moravian-Silesian Region (15); Pardubice (9); Liberec (8); Zlín (7); Vysočina Region (7), Karlovy Vary (3).

\section{CONCLUSIONS}

The outlined overview and the raised problems lead to consideration of the most suitable procedure for the planned construction activities of any plot. The clear first step is to announce the construction plan as soon as possible. Consultations from the time of preparation of the plan are appropriate, although its exact scope is not yet fully known (Figure 7). This is especially true for large infrastructure projects (motorways, railway corridors, large shopping centers etc.) 


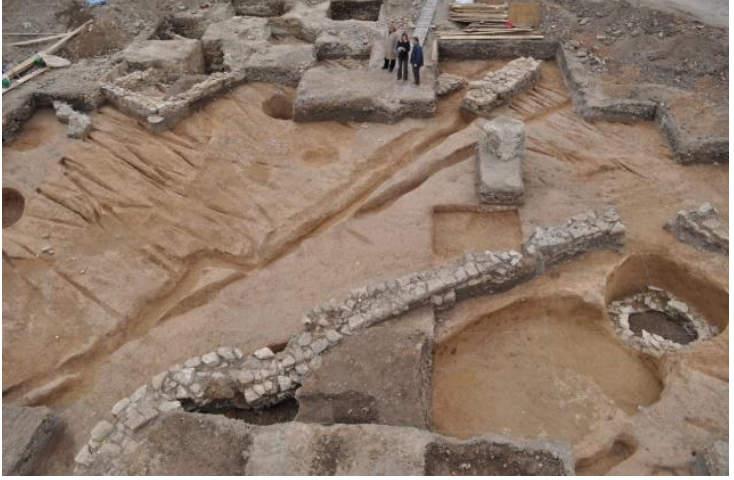

Figure 7. Kutná Hora (Central Bohemia), former Jesuit College. Advance archaeological excavation in 2011 and 2012 following the preparatory stage (survey probes, collection information about older finds). Silver mining workplace from $13^{\text {th }}-15^{\text {th }}$ century.

They are already aware of the number of archaeological finds that will be discovered. It is therefore of interest to know as soon as possible the extent of the archaeological sites in the area affected by the construction activity and, consequently, the time required and the estimated costs. Large developers are already ordering searches of archaeological knowledge about such an area today. They also usually order non-destructive surveys (even with the knowledge that they cannot determine the extent of archaeological finds and situations hidden beneath the surface without any problems). According to the results of research and non-destructive surveys, it is possible to determine the time and financial demands of subsequent (advance) archaeological research and include them in the construction schedule. A seemingly marginal problem remains that, as a result of tenders, searches are often carried out by organizations other than subsequent rescue archaeological research. The first cannot make full use of the preliminary archaeological knowledge of the researched area. The second comes into a situation in which (at least initially) it is not completely oriented. For the builder, this means cost savings, for the knowledge and preservation of cultural heritage, the loss of part of it.

\section{REFERENCES}

Aitchison, K., et alii, 2014: Discovering the Archaeologists of Europe 2012-14: Transnational Report, York National Trust, York.

Cleary, K., Frolík, J., Krekovič, E., Parga-Dans, E., Prokopiu, E.S., 2014: Responding to the Financial Crisis in Five European countries: People, Roles, Reactions and Initiatives in Archaeology. Archeologies: Journal of the World Archaeological Congress 10(3), 211231.

Blažek, J., Lutovská, P., 2002: Prameny k dějinám archeologické památkové péče. Vládní nařízení o archeologické památkové péči z roku 1941. Archeologie ve středních Čechách, 6, 617-639.

Dragoun, Z., 2000: Památkový zákon a případ židovského hřbitova v Praze 1 - Vladislavově ulici. Archeologické rozhledy 52, 447-452.
Ernée, M., Langová, M., et alii 2020: Mikulovice. Pohřebiště starši doby bronzové na Jantarové stezce Early Bronze Age Cemetery on the Amber Road. Archeologický ústav AV ČR, Praha, v. v. i., Praha.

Frolík, J., 2012: Změny v postavení archeologie v souvislosti s př́pravou nového památkového zákona v České republice. Studia Historica Nitrensia, 16(1-2), 208-221.

Frolík, J., Mácalová, M., 2014: Discovering the Archaeologist of Czech Republic 2012-14. Archeologický ústav AV ČR, Praha, v. v. i., Praha.

Frolík, J., Sedláček, R. 2015: Artefakt jihovýchodní provenience z Mikulovic (okr. Pardubice). In: Ožd’áni, O. (ed.), Popolnicové polia a doba halštatská. Archaeologica Slovaca Monographiae, Communicationes 17. Archaeologick ústav Slovenskej Akadémie vied, Nitra, 27-41.

Hlava, M., 2021: Počátky. Kapitola z dějin Státního archeologického ústavu. Archeologie ve střednich Čechách, 25, 499-518

Jošková, T., Langová, M., Jílek, J. (eds.), 2020: Mikulovice. "Zivot na hraně - Life on the Edge. Východočeské muzeum v Pardubicích. Pardubice.

Patrik, M., 2021: Přehled pokut za ničení archeologického dědictví v letech 2013-2020. Zprávy České archeologické společnosti, Supplément 119, 11-12.

Spindler, K., 1998: Muž z ledovce. Mladá fronta. Praha.

Varhaník, J., Malý, S., 2011: Zákon o státni památkové péči. Komentár̆. Praha.

Wallisová, M., 1998: První etapa o výzkumu židovského hřbitova na Novém Městě pražském. Archaeologica Pragensia, 14, 141-148.

Zídek, M., Klusoň, J. 2005: Zákon o státní památkové péči a jeho provádécí predpisy s komentárem. ABF - Arch, Praha. 